Erratum

\title{
Erratum to "A Comparative Study for the Evaluation of Two Doses of Ellagic Acid on Hepatic Drug Metabolizing and Antioxidant Enzymes in the Rat"
}

\author{
Gurbet Celik, ${ }^{1}$ Aslı Semiz, ${ }^{1}$ Serdar Karakurt, ${ }^{2}$ Sevki Arslan, \\ Orhan Adali, ${ }^{2}$ and Alaattin Sen ${ }^{1,3}$ \\ ${ }^{1}$ Department of Biology, Pamukkale University, Kinikli Campus, 20070 Denizli, Turkey \\ ${ }^{2}$ Department of Biochemistry, Institute of Natural and Applied Science, Middle East Technical University, 06800 Ankara, Turkey \\ ${ }^{3}$ Faculty of Art \& Sciences, Biology Department, Pamukkale University, Kinikli, 20070 Denizli, Turkey \\ Correspondence should be addressed to Alaattin Sen; sena@pau.edu.tr \\ Received 1 September 2014; Accepted 16 September 2014; Published 1 December 2014 \\ Copyright (C) 2014 Gurbet Celik et al. This is an open access article distributed under the Creative Commons Attribution License, \\ which permits unrestricted use, distribution, and reproduction in any medium, provided the original work is properly cited.
}

In the paper entitled "A comparative study for the evaluation of two doses of ellagic acid on hepatic drug metabolizing and antioxidant enzymes in the rat", there was an error in Figure 4, and here we provide the right form of Figure 4. 

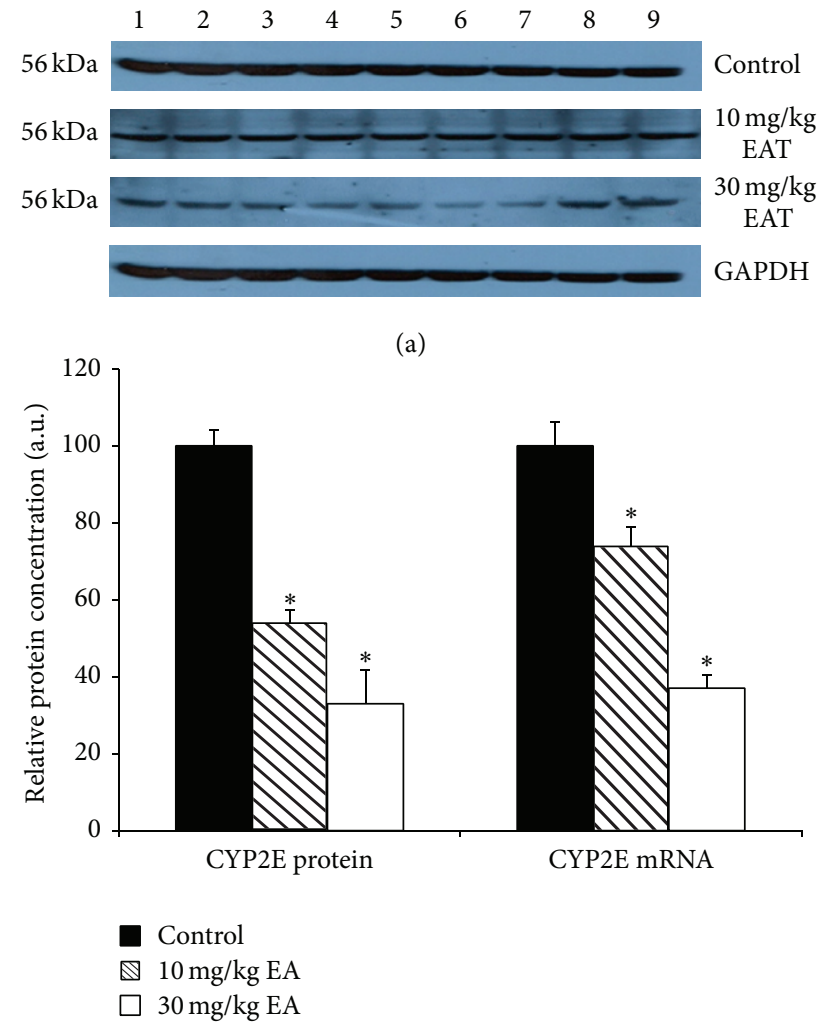

(a)

(b)

Figure 4: Effect of EA on the expressions of CYP2E protein and mRNA in rat liver microsomes. Rats were treated with EA injection and liver microsomes prepared as described in Section 2. (a) The microsomal proteins were separated by SDS-PAGE, and western blot analysis was performed as described in Section 2. Each lane contained $100 \mathrm{mg}$ microsomal protein. Proteins were detected using chemiluminescent substrate for 3 minutes, and bands were visualized and recorded using a DNR LightBIS Pro Image Analysis System. (b) The expression level of CYP2E mRNAs in control rats and rats treated with EA. Treatments were carried out as described in Section 2. The bar graph represents the mean intensity of the bands obtained from western blot and/or qRT-PCR results. Results are presented as the mean from three independent experiments and expressed as relative mean \pm standard deviation. ${ }^{*} P<0.05$, compared with the control group. 

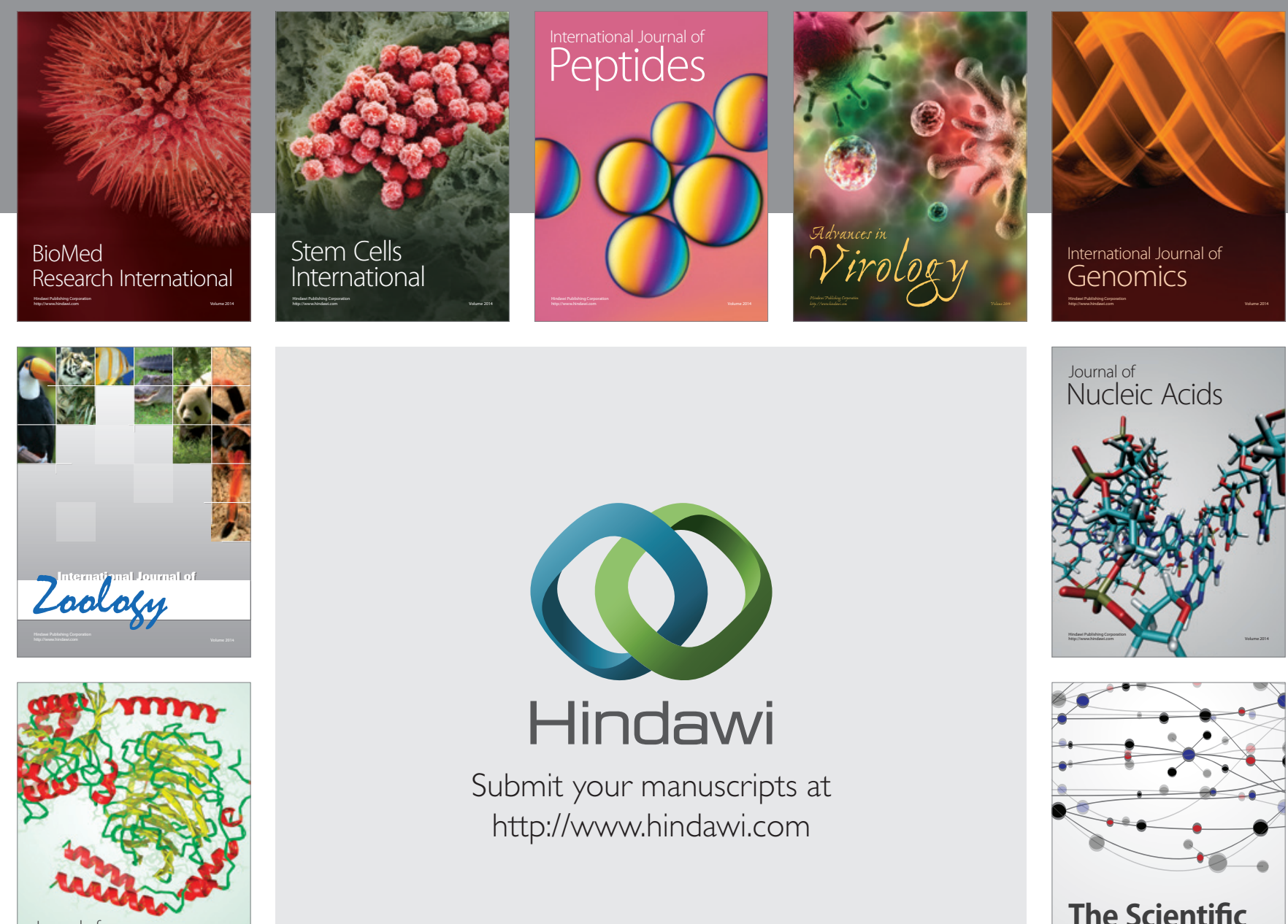

Submit your manuscripts at

http://www.hindawi.com

Journal of
Signal Transduction
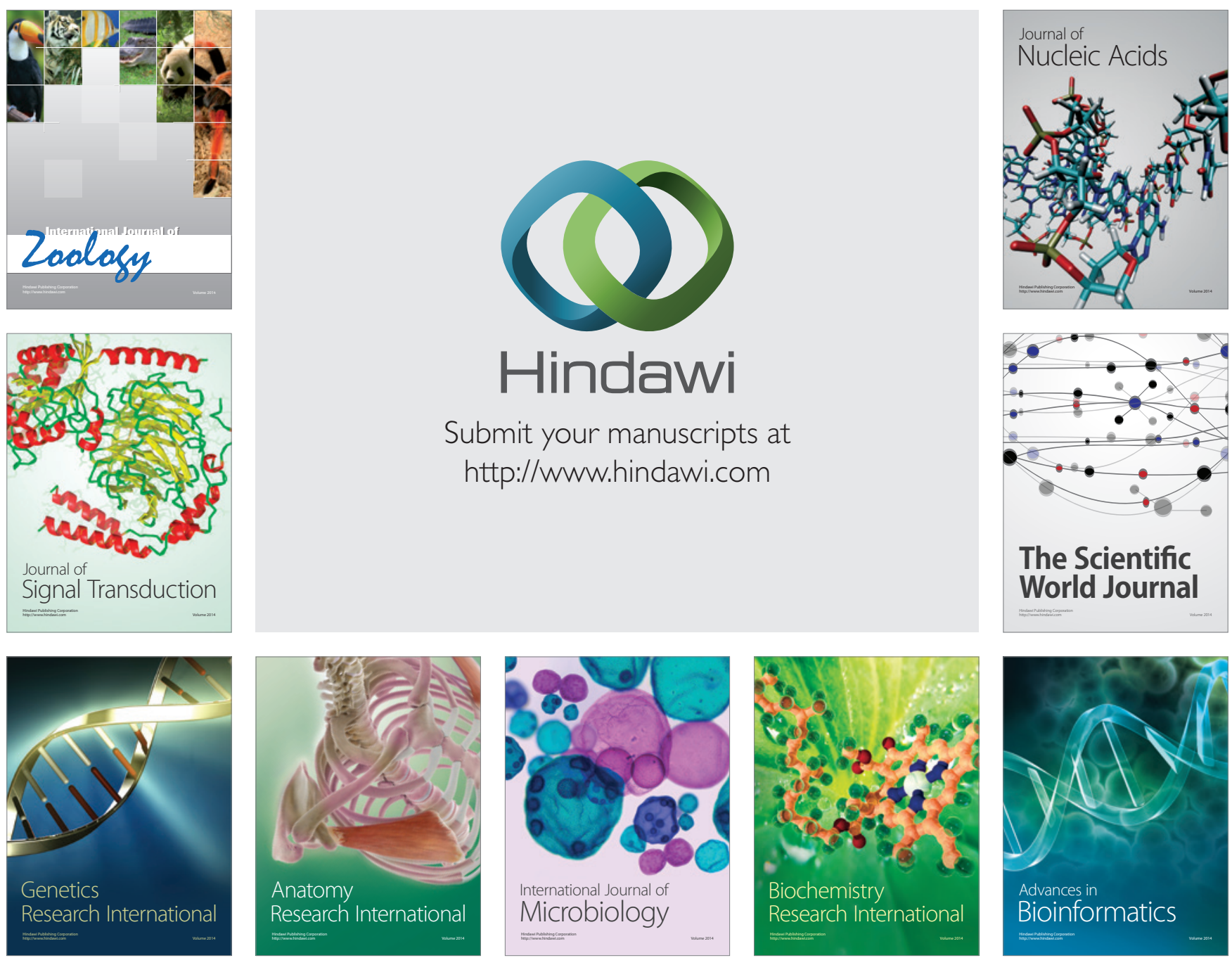

The Scientific World Journal
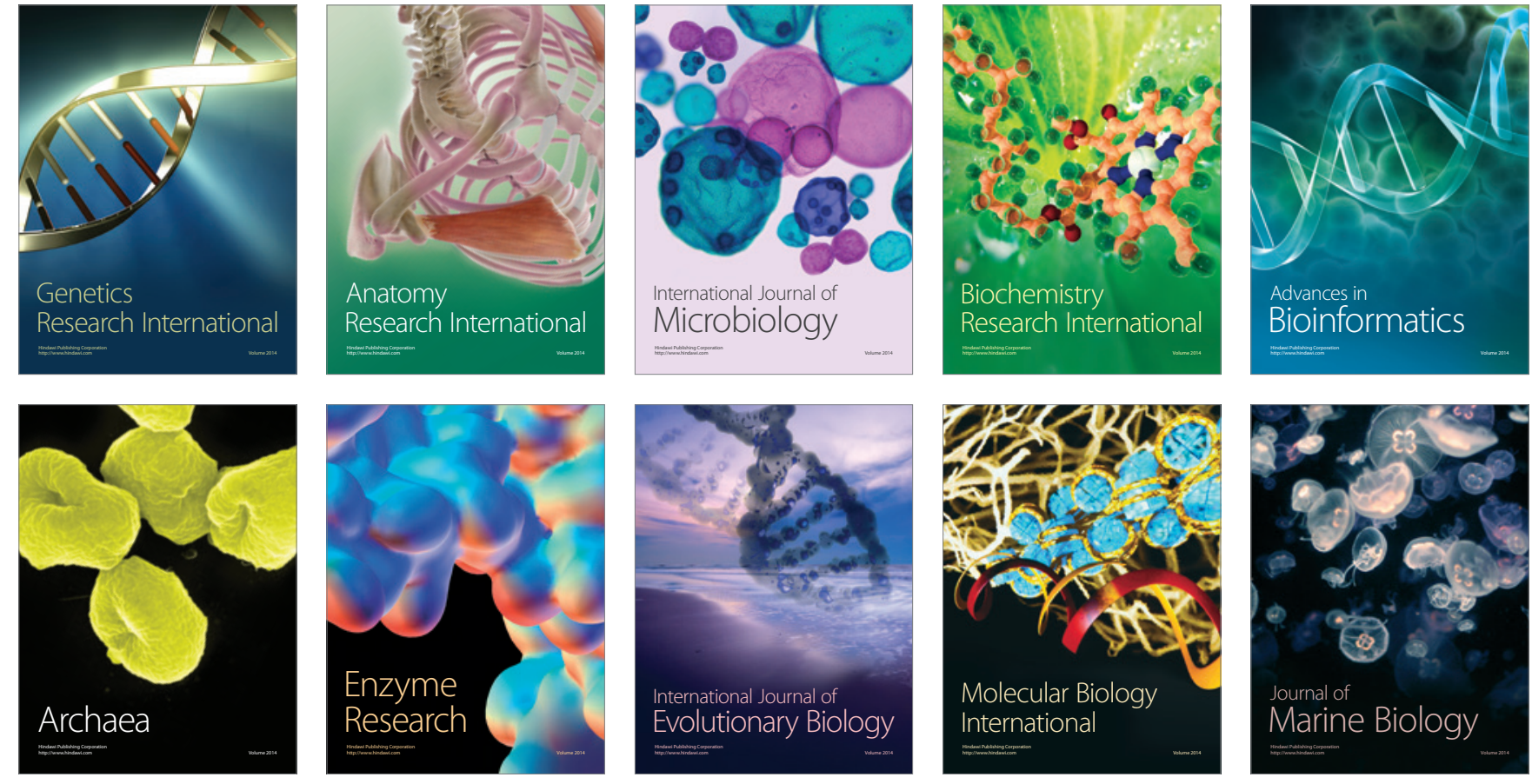